\title{
Phytoremediation of Emulsion Paint Wastewater using Azolla Pinnata, Eichhornia Crassipes and Lemna Minor
}

\author{
E. A. Echiegu, C. O. Ezimah, M. E. Okechukwu, O. A. Nwoke* \\ Department of Agricultural and Bioresources Engineering, University of Nigeria, Nsukka, Enugu State, NIGERIA.
}

\begin{abstract}
The use of three macrophytes namely Azolla pinnata, Eichhornia crassipes and Lemna minor for the phytoremediation of emulsion paint wastewater was investigated. Samples of the paint wastewater and test plants were collected and analyzed for physicochemical characteristics and heavy metal concentrations before and after phytoremediation for six weeks. The TDS of the treated wastewater was reduced by over $80.0 \%$ by each of the test plants while the TSS increased as a result of debris from withered test plants. Dissolved oxygen reduction ranged from $12.5 \%$ to $50.0 \%$, COD from $49.5 \%$ to $57.1 \%$, BOD from $46.7 \%$ to 54.7, heavy metals from 11.0 to $92.5 \%$. A. pinnata appears to have performed significantly better $(P<0.05)$ than the other plants followed by $E$. crassipies and $L$. minor. It can be concluded that the test plants (especially A. pinnata) can be effectively used for the preliminary treatment of paint wastewater.
\end{abstract}

Keywords: phytoremediation, Eichhornia crassipies, Azolla pinnata, lemma minor, paint wastewater, heavy metals

\section{INTRODUCTION}

Water and land are essential resources for human life and is polluted by the anthropogenic actions and industrializations due to the invasive population than other actions [1,2]. The increase in industrial wastewater poses potential health and environmental problems [3]. The introduction of lethal heavy metals into the environment from industrial wastes is a major problem that needs immediate attention [1-4]. Faced with increasingly strict environmental regulations and the increasing exhaustion of water resources, the recycling of wastewater for non-potable purposes (irrigation, domestic non-potable uses, environmental purposes) as well as the treatment of industrial waters for reuse (or just to decrease the chemical pollution) have become a priority for any industrial sector and urban community [3].

The paint industry is one of the major contributors for polluting the soil and water resources with poisonous substances such as $\mathrm{Pb}, \mathrm{Cr}$ and $\mathrm{Cd}$ [2]. Paint industries are major sources of both water and land pollution due to the nature of their operations which requires large volume of water that eventually results in high wastewater generation. In Nigeria and most developing countries, most of these wastes are indiscriminately disposed of in

* Corresponding author (Tel: +234 (0)803 829 9006)

Email addresses: emmanuel.echiegu@unn.edu.ng (E. A. Echiegu), Coezimah@gmail.com (C. O. Ezimah), michael.okechukwu@unn.edu.ng (M. E. Okechukwu), nwoke.oji@unn.edu.ng (O. A. Nwoke) open drainages and arable lands. In the rainy season, these drainages get filled up with rainwater and overflow, thereby resulting in the transport of these heavy metals contained in the paint wastewater to arable lands and water canals which sometimes serves as sources for irrigation water. The paint industry uses about 300 different types of raw materials for production of different kinds and qualities of paints. About $15 \%$ raw materials of this industry is petroleum-based [2]. The major raw material of paint industry is pigments, zinc oxide, titanium oxide, lithopone, mineral, turpentine, resins, vegetable resins and gums. Metal and metal oxides are added to paint for pigmentation, film strength, spreading quality and to enhance weather resistance [2]. The paint is categorized in two broad classes: water-based paint and other solvent based paint. The main source of wastewater in any paint industry is the manufacturing plant water-based paint. The estimated quantity of process wastewater is $3-7 \mathrm{~m}^{3} /$ day for a normal operating day for a typical paint industry [2]. Usually, high volume of wastewater is generated during washing activities at paint industrial units in the water-based paint manufacturing area and water-based resin manufacturing area and lead-chromate pigment manufacturing process zone. The environmental challenges for the paint industry are associated with wastewater generation, air emission and solid waste contaminated with toxic metals such as lead, chromium, and cadmium [2]. Effluents of paint manufacturing company (PMW) contain highly toxic com- 
pounds and organic biorefractory compounds such as COD, BOD and TOC. It harms fish, wildlife, and contaminates the food chain if poured down a storm drain. Paint wastewaters have also adverse effects on human health occupants. If used in closed areas, its chemical components can irritate eyes, skin and lungs and causes headaches and nausea. It can also contribute to respiratory problems; muscle weakness, liver and kidney damage [5]. The PMW must be needed to discharge after treatment due to legal restrictions in organized industrial zone and environment conservation [5].

There are many physical, chemical and thermal methods that have been studied for the treatments of industrial paint wastewater, such as precipitation, adsorption, ion exchange, membrane filtration, evaporation, nanofiltration, using agricultural wastages, reverse osmosis, distillation, coagulation-flocculation, advanced oxidation processes such as ozone, photochemical, Fenton's, electrochemical, and using biological compounds etc. [1-9]. The enormous costs, adverse effects on the environment and low efficiencies associated with these remediation techniques present limitations to their availability and usage $[1,3,7,8]$. Thus, in recent times biological techniques like phytoremediation are being evaluated as alternative options for removal of environmental pollutants due to its low cost and safety of implementation [7]. Phytoremediation is an effective method for removal of harmful heavy metals from the contaminated environment. The genetic term phytoremediation consists of Greek prefix phyto means plants that is attached to the Latin root remedium means to correct or remove an evil [1]. Phytoremediation is a cost-effective and ecofriendly technology that uses living plants to clean up contaminated water, sediments, or soils $[7,8,10]$. Phytoremediation is a plant-based bioremediation technology which employs the engineered use of green plants for the in-situ treatment of polluted soil and water ways [11-13]. It is an environmentally friendly process which takes advantages of the unique and selective uptake abilities of plant roots, in addition to the translocation, bioaccumulation and degradation abilities of the entire plant body. Phytoremediation is cost effective and aesthetically pleasing because the plants can be easily monitored, and metals absorbed by the plants may be extracted from harvested plant biomass and then recycled [12].

Compared to all the removal process phytoremediation is more efficient and cost effective. It takes more time for the removal of contaminants, but the removal is the permanent solution compared with other methods [6]. Unlike humans, plants are having capacity to detoxify heavy metals and it is done through several mechanisms such as organic acids, root reductases, phytochelatins, metallothioneines, mycorrhizae and heat shock proteins [6]. The use of plants in phytoremediation is gaining support as plants have intrinsic abilities to extract and metabolize contaminants and their cooperation with soil microorganisms and endophyte microbes that live inside plants may enhance the removal of contaminants from the environment hence the three major advantages of phytoremediation include low cost, possible in situ remediation and less impact on the environment [2,3].

Heavy metals are the high density metallic chemical elements and are among the important class of contaminants which has increased in the environment due to industrial effluent such as paint wastewater. This increase of heavy metals concentration is of major concern to both humans and the ecosystem because of their nonbiodegradable nature. Quick and necessary measures are required to remediate such polluted systems. This can be achieved through the adoption of an eco-friendly technology such as phytoremediation.

Phytoremediation of heavy metals contaminated water can be readily achieved by aquatic macrophytes [5]. Aquatic macrophytes (submerged, free-floating, and emergent forms), as one of the most important primary producers in freshwater ecosystem, have good absorption ability for contaminants [5]. There have been numerous studies on the capacities of free-floating macrophytes (i.e., Eichhornia crassipes, Lemna minor, and Spirodela polyrrhiza) for removing heavy metals from water [5]. Phytoremediation is the best alternative for tidying up condition, as it is the naturally economical and ecologically practical innovation [6]. Hence, this study was carried out to investigate the use of some selected Nigerian aquatic macrophytes namely: Azolla pinnata (Feathered mosquito fern), Eichhornia crassipes (Water hyacinth) and Lemna minor (Duck weed) for the phytoremediation of paint wastewater, to compare the efficiency of the three selected plants in phytoremediation of paint wastewater, and so minimizing the environmental hazard associated with the discharge of this wastewater onto lands and surface water bodies.

\section{MATERIALS AND METHOD}

\subsection{Collection and Preparation of the Aquatic Plants}

This laboratory study was carried out at the Department of Agricultural and Bioresources Engineering, Faculty of Engineering, University of Nigeria, Nsukka. The Azolla pinnata (mosquito fern) (Fig. 1) used for the study was collected from a water body located in Ologbo, a boundary town between Edo and Delta states, Nigeria. Eichhornia crassipes (water hyacinth) was collected from the Department of Fisheries and Aquatic Resources Management, Michael Okpara University of Agriculture, Umudike, Nigeria while Lemna minor (duck weed) was collected from a water body along Stadium road, Kaduna State, Nigeria. Each of the plants was harvested and transported in clean plastic troughs. They were carefully washed using tap water for two minutes to remove visible debris and then cultured for 14 days in fresh water before the commencement of the treatment. The plants were also analyzed for heavy metals before and after the treatment. 


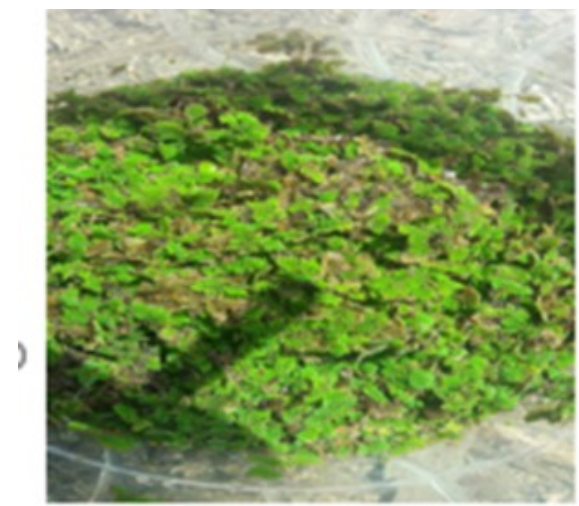

Azolla piñata

(Mosquito fern)

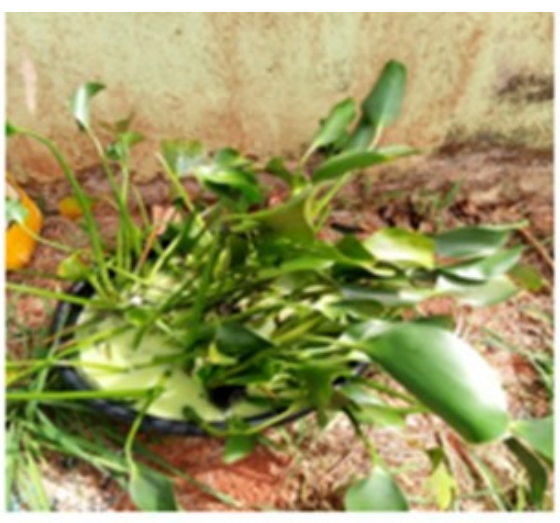

Eichhornia crassipes

(Water hyacinth)

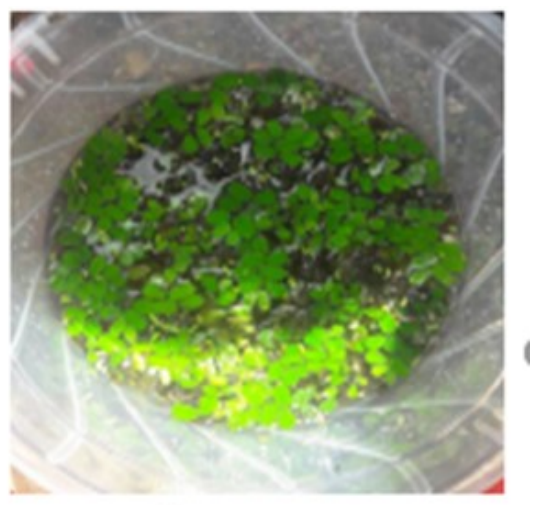

Lemma minor

(Duck weed)

Figure 1: The experimental Plants.

\subsection{Wastewater Sample Collection, Storage and Analysis}

The emulsion paint wastewater used for the study was collected from the emulsion paint effluent discharge chamber of the B-Lux Paint Industries Limited located at Number 1 Okpara Square Azikwe Road Umuahia North, Abia State, Nigeria. The company manufactures emulsion and gloss paints among other things. The emulsion paint wastewater was collected in three (3) clean plastic troughs with a capacity of 25 litres each and transported to the laboratory.

\subsection{Experimental Setup}

Four plastic troughs labelled A, B, C and D were used in the study. The troughs were thoroughly cleaned and the paint wastewater introduced. The trough labelled A served as control (no test plant introduced). The troughs labelled B, C and D contained the three (3) test plants Azolla pinnata, Eich horrnia crassipes and Lemna minor, respectively. The plants were introduced into the trough containing the paint wastewater after the plants were cultured. The experiment lasted for 6 weeks and the setup was closely monitored to prevent external interference such as rain water and debris.

\subsection{Laboratory Analyses}

Samples of the paint wastewater were collected for analyses before the introduction of the aquatic plants and at the end of the experimental period of 6 weeks. The samples were analyzed for total solids (TS), total dissolved solids (TDS), total suspended solids (TSS), total volatile solids (TVS), chemical oxygen demand (COD), biochemical oxygen demand (BOD), dissolved oxygen (DO), oil and greases as per standard methods of analysis of water and wastewater [14]. The $\mathrm{pH}$ and electrical conductivity measurements were done using a HQ40d pH/Conductivity multi-meter ((Hach company, USA) with two separated electrodes. Heavy metals ( $\mathrm{Pb}, \mathrm{Cd}, \mathrm{Hg}, \mathrm{Zn}, \mathrm{Cr}$ and $\mathrm{As}$ ) were analyzed for using Atomic Adsorption Spectrometer
(Shimadzu, Japan model AA-7000). The analyses were carried out at the National Centre for Energy Research and Development, University of Nigeria, Nsukka.

\subsection{Statistical Analysis}

The results were analyzed using the SPSS statistical software version 21. One-Way ANOVA was used to determine differences between treatment means at $5 \%$ level of significance.

\section{RESULTS AND DISCUSSION}

\subsection{Paint Wastewater Characteristics before Phytoremediation Experiment}

The results of the paint wastewater analyses before phytoremediation and the effects of Aquatic Plants on the Physico-Chemical Properties of the Paint Wastewater are shown in Table 1. The initial analyses of the paint wastewater before phytoremediation experiment showed that lead and chromium were absent in the paint effluent sample. However, there was substantial quantity of mercury in the sample. Other heavy metals such as Cadmium, arsenic and zinc were also present (Table 1).

\subsection{Effects of Aquatic Plants on the Physico- Chemical Properties of the Paint Wastewater}

The phytoremediation effects of the aquatic plants on the paint wastewater are shown in Table 1 . The removal efficiency was determined by using the initial concentrations of the given contaminant and the final concentrations at the end of the experiment $[16,17]$ :

Removal Efficiency =

$\left(\frac{\text { Initial Concentration }- \text { Final concentration }}{\text { Initial concentration }}\right) \times 100$ 
Table 1: Results of Paint Wastewater Analyses before Phytoremediation and the Effects of Aquatic Plants on the Physico-Chemical Properties of the Paint Wastewater.

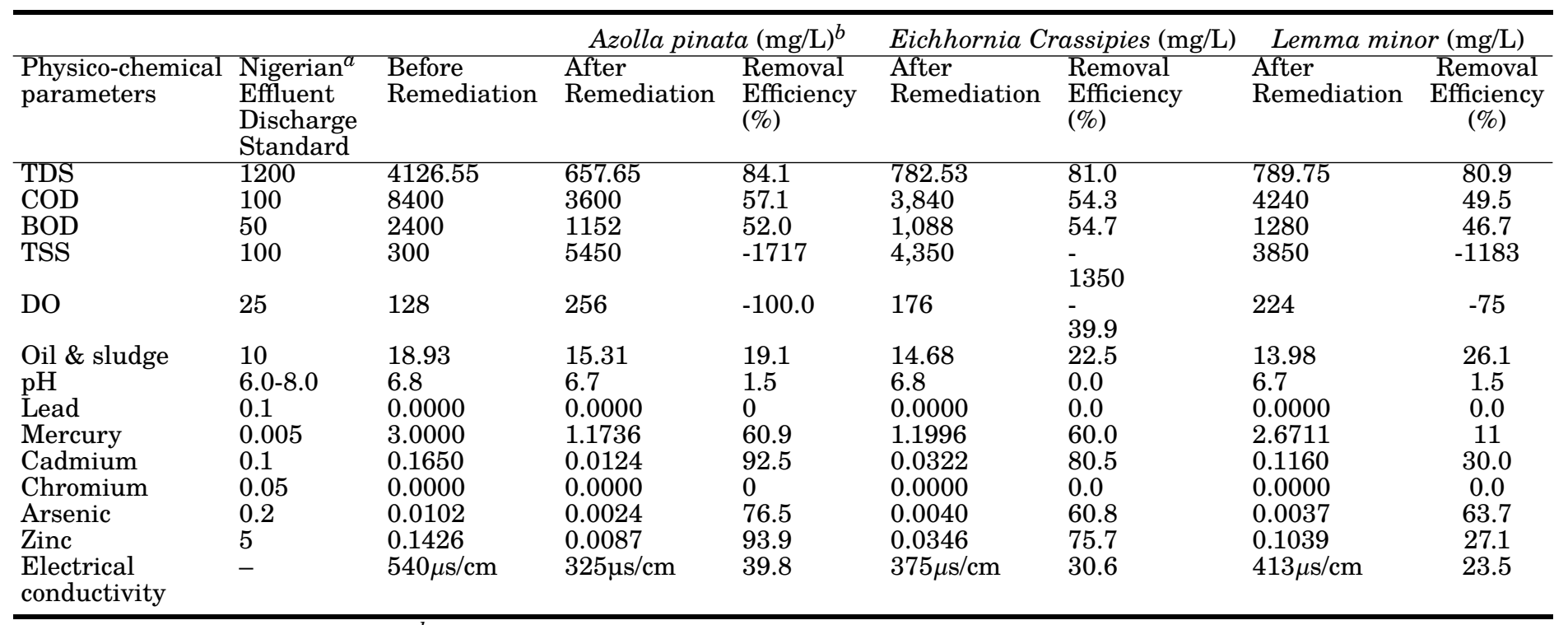

${ }^{a}[15] ;{ }^{b}$ all parameters in $\mathrm{mg} / \mathrm{L}$ except $\mathrm{pH}$ and electrical conductivity

\subsubsection{Solids removal}

The result (Table 1) shows that the removal efficiency for dissolved solids (TDS) was 84.1, 81.0 and $80.9 \%$ for $A$. pinnata, E. crassipies and $L$. minor, respectively. On the other hand, it was observed that the total suspended solids (TSS) of the treated wastewater increased across board for the three plants (Fig. 2). This was as a result of debris from withered test plants which can be attributed to the high concentrations of mercury $(3.0000 \mathrm{mg} / \mathrm{L})$ which inhibits photosynthesis and oxidation metabolism by interfering with electron transport in chloroplast and mitochondria, thereby reducing plant water uptake $[18,19]$. While the final TDS concentrations of the treated wastewater were below the value of $1,200 \mathrm{mg} / \mathrm{L}$ allowed by the Nigerian Effluent Discharge Standard [15], that of the TSS were above the recommended value, indicating that further treatment may be required to reduce the TSS concentration.

\subsubsection{Electrical conductivity (EC)}

Electrical conductivity is related to the dissolved solid content of water and wastewater. As seen in Fig. 3, electrical conductivity was reduced from an initial value of $540 \mu \mathrm{S} / \mathrm{cm}$ to $325 \mu \mathrm{S} / \mathrm{cm}$ by A. pinnata (39.8\% reduction), to $375 \mu \mathrm{S} / \mathrm{cm}(30.6 \%$ reduction) by $E$. crassipes and to $413 \mu \mathrm{S} / \mathrm{cm}(23.5 \%$ reduction) by $L$. minor. The percentage reduction of EC followed similar trend to that recorded for TDS. This is similar to the observation made by [20].

\subsubsection{Dissolved oxygen (DO) and organics}

Table 2 and Fig. 4 show that the DO was decreased by $50.0 \%$ by A. pinnata, $31.3 \%$ by $E$. crassipies and $12.5 \%$ by L. minor. The depletion of oxygen is not a desirable effect of the treatment. This depletion is brought about by the uptake of oxygen by the plant root. This oxygen is used for the oxidation of plant food produced in the process of photosynthesis and subsequent translocation of the food from the leaf to the root. Despite the reduction in the DO content of the wastewater as a result of the treatment, the final values were higher than $50 \mathrm{mg} / \mathrm{L}$ recommended by the Nigerian National Effluent Discharge Standard [15]. Thus, the use of the aquatic plants for wastewater treatment does not adversely affect the DO content of the wastewater. This agrees with the result recorded by [20].

COD reductions for all three plants were similar ranging from $49.5 \%$ for L. minor to $57.1 \%$ for A. pinnata. The BOD of the paint wastewater was reduced by $52.0 \%$ (with $A$. pinnata), $54.7 \%$ (with E. crassipes) and $46.7 \%$ (with L. minor) respectively. The high COD and BOD reduction is attributed to the absorption of dissolved organics by the plant roots which leads to a decrease in the organic matter content. Although there was a reduction in the organic component of the wastewater, the final BOD and COD values were higher that that recommended by the Nigerian Effluent Discharge Standard [15], indicating that further treatment may be required before the wastewater can be discharged onto land or receiving stream.

\subsection{4. $p H$}

The treatment of the wastewater using $A$. pinnata and $L$. minor resulted in a slight decrease in $\mathrm{pH}(1.5 \%)$; E.crassipes did not affect the $\mathrm{pH}$ of the wastewater (Fig. 5). The $\mathrm{pH}$ values recorded with the three plants were within the recommended $\mathrm{pH}$ value of 6.0-8.0 by the Nigerian Effluent Discharge Standard [15].

As seen in Fig. 6, lead and chromium were absent in the raw wastewater. The highest reduction in mercury concentration was achieved using the $A$. pinnata $(60.9 \%)$ followed by $E$. crassipisies 


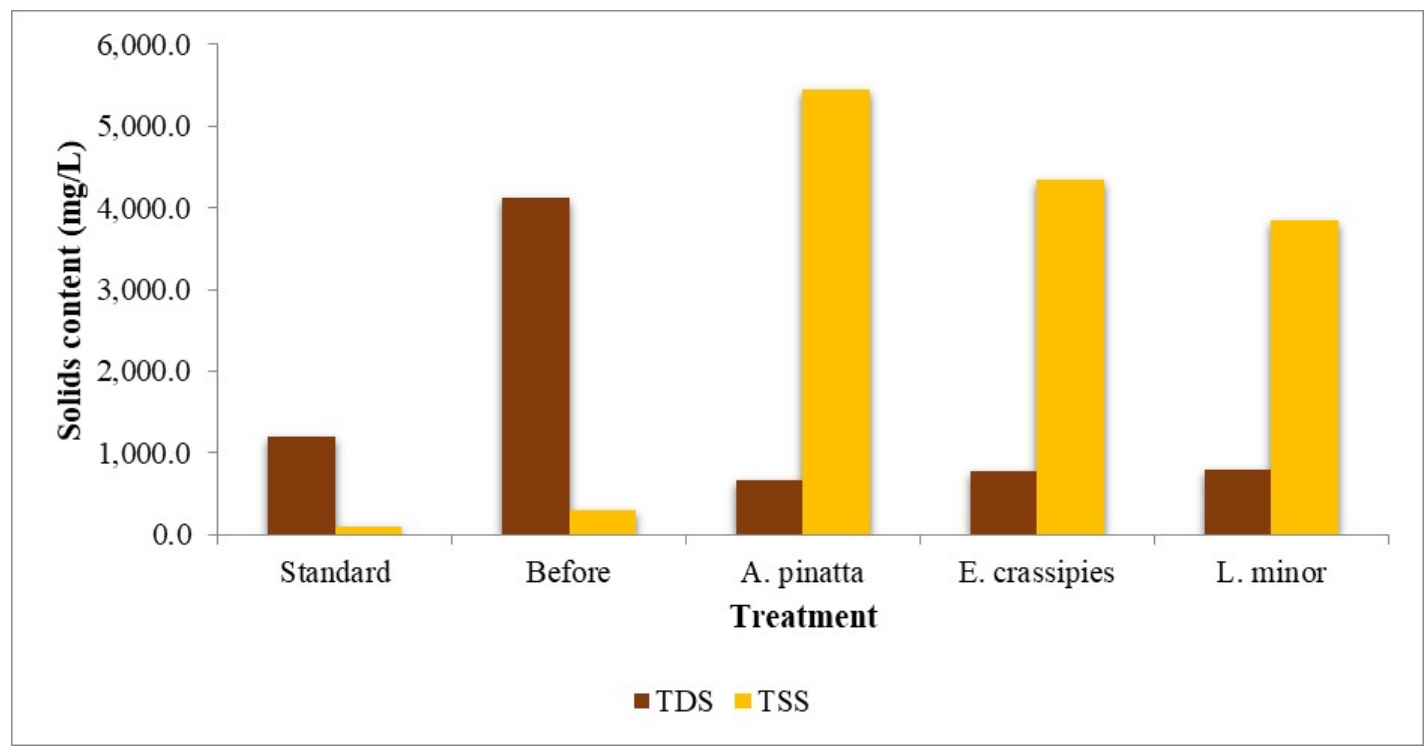

Figure 2: Comparison of solids removal levels for the three aquatic plants.

Table 2: Concentrations of heavy metals in test plants before and after phytoremediation.

\begin{tabular}{|c|c|c|c|c|c|c|c|c|c|c|c|c|}
\hline & \multicolumn{4}{|c|}{ Azolla pinata $(\mathrm{mg} / \mathrm{L})^{b}$} & \multicolumn{4}{|c|}{ Eichhornia Crassipies $(\mathrm{mg} / \mathrm{L})$} & \multicolumn{4}{|c|}{ Lemma minor $(\mathrm{mg} / \mathrm{L})$} \\
\hline & Before & After & $\%$ & $\mathrm{BCF}$ & Before & After & $\%$ & $\mathrm{BCF}$ & Before & After & $\%$ & $\mathrm{BCF}$ \\
\hline & $\begin{array}{l}\text { Remedia- } \\
\text { tion }\end{array}$ & $\begin{array}{l}\text { Remedia- } \\
\text { tion }\end{array}$ & $\begin{array}{l}\text { Incre- } \\
\text { ment }\end{array}$ & & $\begin{array}{c}\text { Remedia- } \\
\text { tion }\end{array}$ & $\begin{array}{c}\text { Remedia- } \\
\text { tion }\end{array}$ & $\begin{array}{c}\text { Incre- } \\
\text { ment }\end{array}$ & & $\begin{array}{l}\text { Remedia- } \\
\text { tion }\end{array}$ & $\begin{array}{c}\text { Remedia- } \\
\text { tion }\end{array}$ & $\begin{array}{l}\text { Incre } \\
\text { ment }\end{array}$ & \\
\hline Lead & 0.0000 & 0.0000 & 0.0 & - & 0.2500 & 0.3000 & 20.0 & - & 1.0500 & 1.0600 & 0.9 & - \\
\hline $\mathrm{Me}$ & & & 20.68 & .063 & & & & & & & 9.9 & 0.131 \\
\hline Cadr & 0314 & 0.0522 & 66.24 & 0.126 & 0.0171 & 0.0192 & 12.2 & 0.013 & 0.1133 & & 7.1 & 0.048 \\
\hline Chromium & 0.7137 & 0.7137 & 0.0 & - & 0.0000 & & 0.0 & - & 0.3122 & & 28.3 & - \\
\hline Arsenic & 0.0081 & 0.0091 & 12.3 & 0.098 & 0.0108 & 0.0122 & 13.0 & 0.137 & 0.0000 & & 0.0 & 0.000 \\
\hline Zinc & 0.0000 & 0.0000 & 0.0 & 0.000 & 0.3550 & 0.4315 & 21.5 & 0.536 & 0.0000 & 0.0000 & 0.0 & 0.000 \\
\hline
\end{tabular}

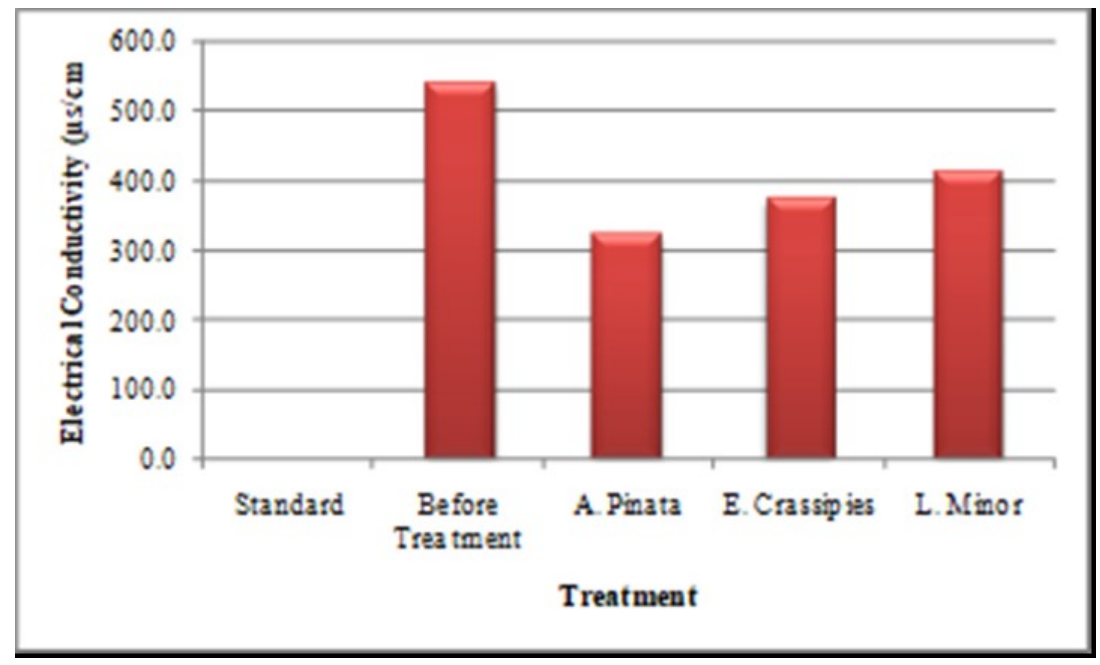

Figure 3: Effects of the treatments on the electrical conductivity of the wastewater. 


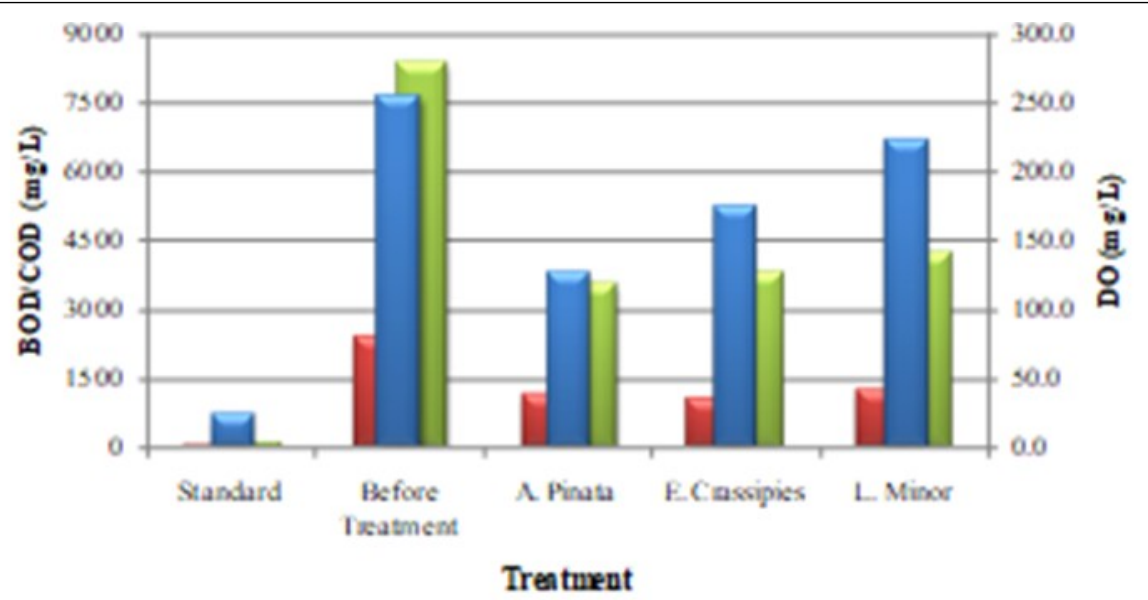

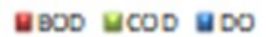

Figure 4: The effects of the treatment on the DO of the wastewater.

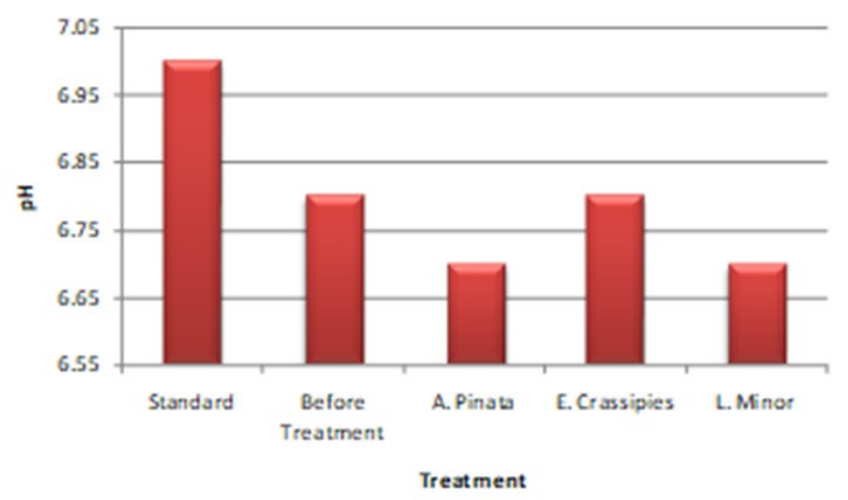

Figure 5: Effects of the three aquatic plants on the $\mathrm{pH}$ of the paint wastewater.

(60.0\%). The lowest value of $11.0 \%$ was achieved using $L$. minor. Cadmium reduction ranged from $30.0 \%$ (for $L$. minor) to $92.5 \%$ (for $A$. pinnata). That of arsenic ranged from $60.8 \%$ (E. crassipies) to $76.5 \%$ (A. pinnata) while that of zinc ranged from $27.1 \%$ (for L. minor) to $93.9 \%$ (for A. pinnata). Arsenic reduction of $0.0024 \mathrm{mg} / \mathrm{L}$ by $A$. pinnata was comparable to the value recorded by [21].

From the point of view of heavy metal reduction, it appears that $A$. pinnata achieved the best result followed by that of $E$. crassipies and $L$. $m i$ nor. The difference in performance of the three aquatic plants in terms of the reduction of mercury, cadmium, arsenic and zinc concentrations of the wastewater was, however, not significantly different $(\mathrm{P}<0.05)$. The final concentrations of $\mathrm{Cd}, \mathrm{Cr}, \mathrm{As}$ and $\mathrm{Zn}$ after the phytoremediation with $A$. pinnata and E. crassipies were below the values recommended by the Nigerian Effluent Discharge Standard [15] while that of $\mathrm{Hg}$ was above, suggesting that further treatment may be needed. For the treatment with $L$. minor, the concentrations of both $\mathrm{Hg}$ and $\mathrm{Cd}$ were higher than the recommended effluent discharge value while $\mathrm{Zn}$ and As were below the recommended value.

\subsection{Bio-accumulation of Heavy Metal by the Test Plants}

The concentration of heavy metals in the test plants prior to and after the remediation is shown in Table 2. As seen in Table 2, all the test plants had some relatively high amount of mercury (> $0.9 \mathrm{mg} / \mathrm{L}$ ) before the experiment. A. pinnata sample also had a high level of chromium ( $>0.7$ $\mathrm{mg} / \mathrm{L}$ ) while the cadmium and arsenic concentration were each below $0.1 \mathrm{mg} / \mathrm{L}$. Lead and zinc were not detected in the plant. For the $E$. crassipies, the concentrations of lead and zinc were relatively much (>0.2 mg/L). There was no chromium, however low levels of cadmium $(0.0171 \mathrm{mg} / \mathrm{L})$ and arsenic $(0.0108 \mathrm{mg} / \mathrm{L})$ were recorded. L. minor had the highest concentration of lead $(1.05 \mathrm{mg} / \mathrm{L})$. Arsenic and zinc were not detected while the level of cadmium was $0.1133 \mathrm{mg} / \mathrm{L}$ and that of chromium, $0.3122 \mathrm{mg} / \mathrm{L}$ in the L. minor tissue sample.

The highest uptake of heavy metal recorded for A. pinnata was cadmium (66.24\%) followed by mercury (20.68\%) and arsenic (12.3\%). There was no uptake of chromium by the plant as this metal ion was not present in the wastewater. For the $E$. crassipies the highest uptake was recorded for mercury $(93.2 \%)$ followed by zinc $(21.5 \%)$, arsenic $(13.0 \%)$ and cadmium (12.2\%). The accumulation of mercury $(0.9317 \mathrm{ppm})$ by $E$. crassipies is higher than the value of $119 \mathrm{ng} / \mathrm{g}$ recorded by [22]. As with $A$. pinnata, chromium was not absorbed by the plant. Although there was no chromium and lead in the wastewater, lead concentrations increased in E.crassipies and L. minor biomass by $20.0 \%$ and $0.9 \%$, respectively while chromium increased in the L. minor biomass by $28.3 \%$. This could be attributed to the fact that the weathered debris of the plant, which already contained chromium and lead, may have been dissolved and the metals absorbed by the L. minor. The uptake of mercury and cadmium by L. minor were $9.9 \%$ and $7.1 \%$, respectively. It would appear that while A. pinnata has the greatest affinity for cadmium, 


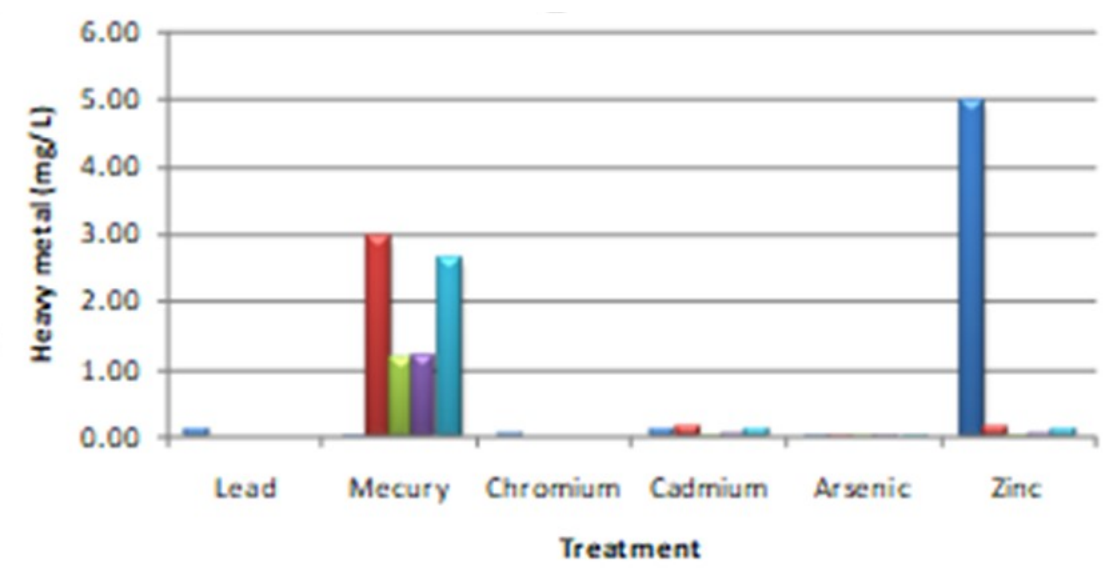

aStandard घBeforeTreatrnent घA.Pinata ME.Crassipies ML.Minor

Figure 6: Heavy metal removal levels by the three aquatic plants.

$E$. crassipies has for mercury while $L$. minor has for chromium.

There was also inhibition of root extension and proliferation as a result of arsenic concentration which also contributed to withering of the test plants. This was particularly observed for $L$. Minor. It was, however, hardly observed for E. Crassipes, probably due to the broad nature of its stem and leaves, and well root spread.

\subsection{Bio-Conversion Factor $(\mathrm{BCF})$}

In order to determine the ability of the plant to accumulate metal with respect to the concentration of the metal in the wastewater, an index known as the Bio-conversion Factor (BCF) was used. The initial concentration of heavy metals in the substrate is a major factor that influences the uptake efficiency of the metal by the plant. $\mathrm{BCF}$ is, therefore, a useful parameter for evaluating the potential of the plants to accumulate heavy metals, i.e. the phytoremediation potential of the plant [23-25]. Generally, when the heavy metal concentration in wastewater increases, the amount of metal accumulation in plants tissue increases [26, 27]. BCF is calculated as follows [2830].

\section{$\mathrm{BCF}=$}

Concentration of metal in plant tissue

Initial concentration of metal in external solution

The BCF for the three test plants are shown in Table 2. A. pinnata recorded the highest BCF of 0.126 for $\mathrm{Cd}$ and 0.000 for $\mathrm{Zn}$. BCF was not computed for $\mathrm{Pb}$ and $\mathrm{Cr}$ since these were not present in the wastewater. For $E$. crassipies the computed $\mathrm{BCF}$ ranged from 0.013 for $\mathrm{Cd}$ to 0.536 for $\mathrm{Zn}$. BCF of 0.131 and 0.0 was recorded by L. Minor for $\mathrm{Hg}$ and $\mathrm{Cd}$, respectively. These values are similar to the value of 0.3 to 0.85 recorded by [30] for $\mathrm{Cr}$ (IV) using processed water from Sukinda chromite mines.

\subsection{Statistical Comparison of the Perfor- mances of the Three Plants}

The ANOVA results indicates that there was a significant difference $(\mathrm{P}<0.05)$ in the reduction of the TDS, COD, BOD, Oil and sludge and as well the $\mathrm{pH}$ by the three test plants. There was no significant difference $(\mathrm{P}<0.05)$ between the three plants in terms of DO depletion, TSS reduction and EC. There was also no significant difference $(P<0.05)$ between the three aquatic plants in the reduction of mercury, cadmium, arsenic and zinc.

\section{CONCLUSIONS}

From the results of the tests and analysis carried out in this study it can be concluded that the three aquatic plants - Azolla pinnata, Eichhornia crassipes and Lemna minor - can be effectively used in the preliminary treatment of emulsion paint wastewater as they were shown to considerably reduce the level of contaminants in the paint effluent. Of the three aquatic plants used in the study, Azolla pinnata recorded the highest percentage reduction in heavy metals, solids and other organic components. The accumulation of heavy metal by the test plant ranged from 0 to $93.2 \%$, depending on the plant and the heavy metal type. It appears that while A.pinnata had greater affinity for cadmium, E.crassipies had for mercury while $L$. minor had for chromium. Some of the parameters monitored in paint wastewater such as heavy metals, solids and dissolved oxygen were above threshold when compared to the National Standard for effluent discharge, indicating that the use of these plants alone may not be sufficient for the treatment of emulsion paint wastewater.

As plant uptake of contaminant is plant species dependent, not all species possess superior capability to extract and metabolize contaminants hence additional research work is needed to investigate other plants (particularly local plant species) with potential phytoremediation applications [as plant uptake, accumulation and translocation of organic pollutants vary greatly depend- 
ing on plant species, organic pollutant characteristics and environmental conditions. Since the study was based on three selected floating macrophytes we suggest further research using other species of floating macrophytes as well as comparison with remediation using submerged macrophytes. Because phytoremediation takes more time for the removal of contaminants, we also recommend further research extending the remediation period for more than six weeks as obtained in this study for improved result.

\section{References}

[1] S. Jeevanantham, A. Saravanan, R. Hemavathy, P. Kumar, P. Yaashikaa, and D. Yuvaraj, "Removal of toxic pollutants from water environment by phytoremediation: A survey on application and future prospects," Environmental Technology and Innovation, vol. 13, pp. 264-276, 2019

[2] M. Gondal and T. Hussain, "Determination of poisonous metals in wastewater collected from paint manufacturing plant using laser-induced breakdown spectroscopy," 2006.03.022 Talanta, vol. 71, no. 1, pp. 73-80, 2019.

[3] S. Bouranene, N. Sedira, P. Fievet, and N. Attia, "Treatment of paint wastewater by coagulation process," Filtration and Separation, vol. 52, no. 4, pp. 42-45, 2015.

[4] K. M. Oghenejoboh, "Biosorption of nickel (II) ion from synthetic wastewater on watermelon rind activated carbon using reponse surface methodology (RSM) optimization approach," Nigerian Journal of Technology, vol. 37, no. 3, p. 647, 2018.

[5] A. Akyol, "Treatment of paint manufacturing wastewater by electrocoagulation," Desalination, vol. 285, pp. 91-99, 2012

[6] G. Akpen, M. Aho, and N. Baba, "Adsorption of cadmium (II) from simulated wastewater using Albizia saman pod activated carbon in fixed bed columns," Nigerian Journal of Technology, vol. 37, no. 3, p. 833, 2018.

[7] O. Izinyon and A. Seghosime, "Assessment of Sweet Potato (Ipomoea Batatas) for Phytoremediation of Motor Oil Contaminated Soil," Nigerian Journal of Technology, vol. 32, no. 3, pp. 371-378, 2013.

[8] B. Li, B. Gu, Z. Yang, and T. Zhang, "The role of submerged macrophytes in phytoremediation of arsenic from contaminated water: A case study on Vallisneria natans (Lour.) Hara," Ecotoxicology and Environmental Safety, vol. 165, pp. 224-231, 2018.

[9] D. Güven, O. Hanhan, E. Aksoy, G. Insel, and E. Çokgör, "Impact of paint shop decanter effluents on biological treatability of automotive industry wastewater," Journal of Hazardous Materials, vol. 330, pp. 6167, 2017.

[10] M. Ayotamuno, R. Kogbara, R. State, and C. Author, "Comparative analysis of some techniques in the biological reclamation of crude oil polluted agricultural soils in nigeria," Nigerian Journal of Technology, vol. 25, no. 1, pp. 15-26, 2006.

[11] D. Salt, M. Blaylock, and P. Kumar, "Phytoremediation: a novel strategy for the removal of toxic elements from the environment using plants," Biotechnology, vol. 13, pp. 468-474, 1995 .

[12] A. Sood, P. Uniyal, R. Prasanna, and A. Ahluwalia, "Phytoremediation potential of aquatic macrophyte, azolla," Ambio, vol. 41, no. 2, pp. 122-137, 2012.

[13] B. Dhir, Phytoremediation: Role of aquatic plants in environmental clean-up, ser. 978-81-322-1306-2. New york Dordrecht London: Springer New Delhi, 2013.

[14] Standard methods for the analysis of water and waste water, 19th ed., Washington D.C, 1998, american Public Health Association (APHA).

[15] FEPA, "Effluent limitation guidelines in nigeria for all industries," Federal Environmental Protection Act. Second Schedule (Regulation 3). Government Printer, Lagos, 1988.

[16] A. Ugya, "The Efficiency of Lemina minor L. in the phytoremediation of Romi Stream. A Study of Kaduna Refinery and Petrochemical Company Polluted Stream,"
Journal of Applied Biology and Biotechnology, vol. 3 , no. 1, pp. 011-014, 2015

[17] A. Ugya and T. Iman, "The efficiency of Eichhornia crassipies in the phytoremediation of waste water from Kaduna refinery and Petrochemical company," IOSR Journal of Environmental Science, Toxicology and Food Technology (IOSR-JESTFT), vol. 9, pp. 43-47, 2015.

[18] A. Sas-Nowosielska, R. Galimska-Stypa, R. Kucharski, U. Zielonka, E. Małkowski, and L. Gray, "Remediation aspect of microbial changes of plant rhizosphere in mercury contaminated soil," Environmental Monitoring and Assessment, vol. 137, no. 1, pp. 101-109, 2008.

[19] B Tangahu, S. Abdullah, H. Basri, M. Idris, N. Anuar, and M. Mukhlisin, "A Review on Heavy Metals (As, Pb and $\mathrm{Hg}$ ) Uptake by Plants through Phytoremediation," International Journal of Chemical Engineering, 2011.

[20] N. Mudavanhu, A. Ndeketeya, and N. Masaya, "An assessment of phytoremediation capacity of Eichhornia crassipes and Typha capensis for the removal of total dissolved solids in plastic recycling industry wastewater," IOSR Journal of Environmental Science, Toxicology and Food Technology (IOSR), vol. 8, no. 1, pp. 86-92, 2014.

[21] A. Ugya, T. Imam, and A. Hassan, "Phytoremediation of textile wastewater using azolla pinnata," World Journal of Pharmaceutical Research, vol. 6, no. 2, pp. 1142$1150,2017$.

[22] M. Molisani, R. Rocha, W. Machado, R. Barreto, and L. Lacerda, "Mercury contents in aquatic macrophytes from two reservoirs in the paraíba do sul:guandú river system, se brazil," Brazilian Journal of Biology, vol. 66, pp. 101-107, 2006.

[23] F. Zhao, E. Lombi, and S. McGrath, "Assessing the potential for zinc and cadmium phytoremediation with the hyperaccumulator thlaspi caerulescens," Plant Soil, vol. 249, no. 1, pp. 37-43, 2003.

[24] X. Lu, M. Kruatrachue, P. Pokethitiyook, and K. Homyok, "Removal of cadmium and zinc by waterhyacinth, eichhornia crassipes," Sci Asia, vol. 30 pp. 93-103, 2004

[25] J. Yoon, C. Xinde, Z. Qixing, and Q. Lena, "Accumulation of $\mathrm{Pb}, \mathrm{Cu}$, and $\mathrm{Zn}$ in native plants growing on a contaminated Florida site," Sci. Total Environ, vol. 368, no. 2, pp. 456-464, 2006

[26] W. Wang and M. Lewis, Metal accumulation by aquatic macrophytes, W. Wang, J. Gorsuch, and J. Hughes, Eds. New York: Lewis Publishers, 1997, plants for Environment Studies.

[27] N. Karimi, S. Ghaderian, A. Raab, J. Feldmann, and A. Meharg, "An arsenic-accumulating, hypertolerant Brassica isatis, Cappadocica," New Phytol, vol. 184, pp. 41-47, 2009.

[28] A. Zayed, S. Gowthaman, and N. Terry, "Phytoaccumulation of trace elements by wetland plants: I. Duckweed," Journal of Environmental Quality, vol. 27, pp. $715-721,1998$

[29] M. Thayapara, S. Iqbal, P. Chathuranga, and M. Iqbal "Rhizofiltration of $\mathrm{Pb}$ by Azolla pinnata," International Journal of Environmental Sciences, vol. 3, no. 6, 2013.

[30] P. Saha, O. Shinde, and S. Sarkar, "Phytoremediation of industrial mines wastewater using water hyacinth," International Journal of Phytoremediation, vol. 19, no. 1 , pp. 87-96, 2017. 